POLSKA AKADEMIA UMIEJĘTNOŚCI

PRACE KOMISJI KULTURY SŁOWIAN PAU

TOM XI

\author{
Hanna Kowalska-Stus
}

Uniwersytet Jagielloński, Kraków

\title{
GLOBALIZACJA VERSUS MISJONIZM. KONFRONTACJA GEOKULTURY ZACHODNIEJ I ROSYJSKIEJ
}

W latach 90. Zachód występował w roli zwycięzcy. Wtedy nieliczni politologowie zachodni zadawali sobie pytanie, czy chodzi o zwycięstwo nad ZSRR, czyli komunizmem, a więc zwycięstwo wartości chrześcijańskich nad materialistycznymi, czy zwycięstwo polityczne. Geopolityczny twór - ZSRR przestał istnieć. Nikt nie okazał się jego spadkobiercą. Rosjanie, choć mogli w tym momencie dowodzić, że są najbardziej przez komunizm pokrzywdzeni i starać się odbudować przedrewolucyjną utraconą monarchię, także w sensie geopolitycznym, nie uczynili tego. Zarówno w samych ówczesnych wydarzeniach historycznych, jak i w ich opisie do dzisiaj panuje chaos. Postronnemu obserwatorowi trudno byłoby na ich podstawie zrozumieć, co się wydarzyło wraz z końcem ZSRR. Tylko jedno jest oczywiste: zmiana kształtu mapy geograficznej w tej części świata. Zadajmy kilka podstawowych pytań, jakie mogą nasunąc się na podstawie lektury zachodnich opracowań:

1. Czy zmienił się ustrój polityczny na dawnym obszarze ZSRR i bloku wschodniego? Jeśli tak, to na jaki?

2. Czy zmieniła się kultura na tym terenie? Jeśli tak, to ze źródeł jakich wartości ona wyrasta?

3. Czy zmieniły się stosunki społeczne? Jeśli tak, to jakie wartości stanowią ich nową podwalinę?

4. Czy zmienił się system oświecenia i wychowania społecznego? Jeśli tak, to na jakich wartościach się opiera i jakie cele wyznacza jednostce i społeczeństwu?

5. Czy zmieniły się elity? Jeśli tak, to jakie wartości wyznają?

W tym natrętnym pytaniu o wartości nie chodzi o kwestie moralne, tylko o podstawę ontologiczną, która powinna być czytelna w momencie odrzucenia starego systemu, który po rewolucji 1917 r. fundowany był na precyzyjnie określonej ontologii. Na niej budował ustrój polityczny, społeczny, kulturę, oświatę i wychowanie, ją wyznawały jego elity. Najpierw zdefiniowano, c z y m jest świat i k i m jest człowiek, 
a potem określono hierarchię wartości, na podstawie których dawano odpowiedź na pytanie, jaki e mają być wymienione byty. Leninizm jako swoista religia opierał się na ontologii przeciwstawnej prawosławiu.

Po 1990 r. cywilizacja Zachodu pełniła jakiś czas rolę propozycji zastępczej wobec skompromitowanego komunizmu. Szybko okazało się jednak, że państwa zachodnie nie opierają się na jasno sformułowanej wizji człowieka i świata, ich system społeczno-polityczny reprezentuje tylko swoistą gęstą strukturę prawno-ekonomiczną zanurzoną w ideologii liberalnej. Trudno tu mówić o wspólnym systemie wartości czy światopoglądzie. Skoro jednak w tej strukturze dużą rolę odgrywa prawo pozytywne, można było w tej jednej dziedzinie próbować odnaleźć spójny system wartości. To też jest rzeczą bardzo trudną, gdyż prawo jest nieustannie modyfikowane zgodnie z kalendarzem wyborczym i indywidualnymi zapatrywaniami różnych partii. Ono również nie posiada ontologii. Kwestia światopoglądu jest tu podstawowa dla zrozumienia problemu poglądów geopolitycznych Rosjan.

W danym momencie historycznym (2014), w trakcie wydarzeń na Ukrainie, warto skupić uwagę przede wszystkim na wypowiedziach Aleksandra Dugina, który pełni rolę ideologa partii Jedinaja Rossija. W ciagu ostatnich czterech miesięcy wielokrotnie wypowiadał się w programach głównych stacji telewizyjnych. Wypowiedzi te stanowią uaktualnienie geopolitycznych i geokulturowych poglądów Dugina, które legły u podstaw programu partii Jedinaja Rossija i prezydenta Putina, począwszy od jego drugiej kadencji. Ich osią jest teza o konfrontacyjnym charakterze istnienia dwóch cywilizacji: amerykańskiego atlantyzmu i rosyjskiego euroazjatyzmu.

W porównaniu z wcześniejszymi pracami Dugina obecnie koncentruje on uwagę na zagadnieniach geokultury: geopolityka jest pochodną obrony, ekspansji bądź zderzenia tradycji kulturowo-cywilizacyjnych. Dużo uwagi Dugin poświęca analizie rozwoju cywilizacji zachodniej od premodernizmu przez modernizm do postmodernizmu.

Telos - celowość historii zachodnioeuropejskiej, według Dugina, zakłada rozwój od premodernizmu do postmodernizmu. Traktowany jest jako uniwersalny, na jego podstawie wypracowano system kryteriów postępowości obowiązujący w całym współczesnym świecie ${ }^{1}$. Według tych kryteriów pisane są podręczniki historii. Paradoks polega na tym, że modernizacja Rosji w XX w. odbywała się według innych kryteriów - leninowskich. Dugin podkreśla, że do dziś jeszcze niejasne jest, jaką rolę ona odegrała.

Nawet jeśli przyjąć, że komunizm pełnił rolę modernizmu, to zachodni postmodernizm nie może być na tym gruncie przyjęty, ponieważ stanowi zaprzeczenie zachodniego modernizmu. Niemniej jest akceptowany przez prozachodnie elity w Rosji, które przyjęły go jako stymulator jej rozwoju². Chciały one szybko zdemontować to, co w rze-

${ }^{1}$ А. Дугин, Геополитика постмодерна. времена новых империй. Очерки геополитики ххі века, http://modernlib.ru/books/dugin_aleksandr/geopolitika_postmoderna (dostęp: 10.05.2014).

${ }^{2}$ Warto zauważyć, że istnieje różnica między postmodernizmem w cywilizacji zachodniej i rosyjskiej. W rosyjskiej idea postmodernizmu pojawiła się w myśli Bierdiajewa w związku z potraktowaniem 
czywistości było w Rosji pseudomodernistyczne. Styl transformacji w Rosji w latach 90. dążył do bezwzględnej realizacji telosu zachodniej cywilizacji, podczas gdy logika rozwoju historycznego Rosji sprzeciwiała się temu. Postmodernizm w wydaniu zachodnim niweluje destrukcyjną wymowę modernizmu w stosunku do tradycyjnych wartości społecznych. W postmodernizmie nikt nie buntuje się przeciwko modernistycznemu zaprzepaszczeniu tradycji, gdyż wyzwala ona już tylko obojętność, nie posiada żadnej treści. W postmodernizmie nie ma antagonistów ani w sferze społecznej, ani ekonomicznej, ani psychologicznej, ani cywilizacyjnej. Postmodernizuje się także świadomość historyczną. Sztuczne zaszczepienie postmodernizmu na gruncie rosyjskim, pojawienie się go w obcym kontekście kulturowo-cywilizacyjnym, zauważa Dugin, może wywołać nadspodziewane rezultaty. Swój pogląd opiera na spostrzeżeniu, że w Rosji sfera premodernizmu okazała się na tyle żywotna, że poprzerastała racjonalny program leninowskiego modernizmu i w związku z tym możliwe jest odrodzenie tradycyjnego społeczeństwa.

Postmodernizm zmienił także sens terminu ,imperium” w języku politologów. Funkcjonuje on jako synonim globalizacji ${ }^{3}$. Dugin posługuje się tu definicją Thomasa Barnetta (the Core, imperium jako centrum retlanslacji kognitywnych, ekonomicznych, ontologicznych paradygmatów składających się na treść globalnej informacji). Zgodnie z oczekiwaniami tego imperium Rosja po rozpadzie ZSRR winna była stworzyć państwo narodowe, dokonać na jego gruncie modernizacji: zbudować społeczeństwo obywatelskie i rozpłynąć się w globalnej cywilizacji. Jednak, zauważa Dugin, zgodnie z logiką postmodernizmu, Rosja może rozwijać się w dowolnym kierunku: zarówno ku przyszłości, jak i ku przeszłości. Jednym z kierunków jest Związek Euroazjatycki jako globalne kontrimperium, jako odmowa uczestnictwa w globalistycznej konkurencji. Postmodernizm odsłania też perspektywę eschatologiczną. Eurazjatyzm dąży do odbudowy Imperium, ale celem nie są korzyści terytorialne lub ekonomiczne. Imperium, zgodnie z tradycją bizantyjska, rozumiane jest jako przestrzeń zbawcza, są to więc cele eschatologiczne ${ }^{4}$.

Dugin podkreśla, że wyjątkowość eurazjanizmu jako filozofii politycznej polega na tym, że otwiera nowe perspektywy, jest postmodernistyczny inaczej. Jego zasady są następujące:

- dopuszcza obumarcie państw narodowych, na ich miejscu powstanie kilka kontynentalnych imperiów;

komunizmu jako szczytowej, wynaturzonej formy moderny Por. Н. Бердяев, Новое средневековье, http://royallib.com/read/berdyaev_nikolay/novoe_srednevekove.html\#0 (dostęp: 10.05.2014).

${ }^{3}$ Współcześni rosyjscy politologowie często to zagadnienie interpretują w duchu rosyjskiego postmodernizmu: „Идея государства-нации базируется на либерально-светской идеологии. Это секулярный проект, в котором церкви и религии отводится место далеко «на галерке», Империя, в отличие от государства-нации, не может себе позволить быть секулярной. Если она это делает, она распадается. Народные массы должна объединять более мощная идея, чем понятие рынка"; В. Скворцов, Святая Русь как антипод государства-нации, http://www.ruska-pravda.com/ideologiya/ (dostęp: 10.05.2014).

${ }^{4}$ Укрепление единства российской нации и этнокультурное развитие народов России (20142020 годы) подписанная премьером федеральная целевая программа, http://fond-sblizhenie.ru/ (dostęp: 10.05.2014). 
- imperia te oderwą się od swoich granic i staną się tak samo globalne jak atlantyckie, swoje wartości uczynią uniwersalnymi;

- zmieni się etyka płci i powróci do swoich form archaicznych;

- Eurazja winna stać się gospodarzem widowiska postmodernizmu.

Ponieważ napaść Amerykanów na Irak jest znakiem końca pojałtańskiego świata, a instytucje międzynarodowe ówczesnego porządku światowego (ONZ, NATO, UNESCO i inne regionalne organizacje) przestały odgrywać rolę stabilizująca, świat może rozwijać się według dwóch scenariuszy.

1. Jednobiegunowo z nieograniczoną dominacją USA. Znakiem tego był fakt, że podczas szczytu w Bratysławie w 2005 r. Bush nakreślił granice samodzielności polityki zagranicznej i wewnętrznej Rosji. Zabronił Rosji uprawiać samodzielną politykę w stosunku do Ukrainy, Mołdawii, Iranu, Syrii i Korei Północnej. USA określiły ramy rosyjskiej geopolityki, a polityka wewnętrzna winna być zgodna z amerykańskimi normami.

2. Wielobiegunowo. Biegunami będą: Unia Europejska, Eurazja, świat islamu, japońsko-chińskie kondominium, Afryka transsacharyjska, Panameryka...

Jeśli Rosja chce przyczynić się do budowy świata wielobiegunowego, to jej główne zadanie, zdaniem Dugina, polega na tym, aby na zachodnich granicach zaczynała się strefa kontynentalnej Europy, nie proamerykańskiej, nie anglosaskiej, nie „kordonu sanitarnego"s. Taka kontynentalna Europa może być albo niemiecka, albo wschodnioeuropejska ze słowiańską tożsamością. Niemiecki sektor wpływów powinien albo sąsiadować z rosyjskim, albo obydwa powinny nakładać się na siebie w warunkach subtelnej równowagi. Winny się konsolidować wobec anglosaskiej talassokracji, finansowej oligarchii i amerykańskiej hegemonii. Między nimi winna istnieć złożona mozaika narodów i krajów, skłaniających się ku jednemu bądź ku drugiemu biegunowi. Możliwość realizacji tej idei spędza sen z powiek Brzezińskiego, ucznia Mackindera, to koniec nowego porządku światowego. Dugin twierdzi, że celem geopolityki rosyjskiej jest wyzwolenie Europy od atlantyckich okupantów, tych samych, którzy doprowadzili do katastrofy w Kijowie. Rosja winna walczyć nie o Europę rosyjska, o wolną Europe, o Europę ducha, kultury, tradycji i etosów. Aby zapewnić sobie samym bezpieczeństwo, Rosjanom przyjdzie udzielić pomocy Europejczykom, by ci odzyskali władzę w swoje ręce.

Nazywaliście nas ,żandarmem Europy”. Rzeczywiście, jesteśmy nim. Karzemy przestępców i zakuwamy w kajdany buntowników. Stoimy na straży zdrowej rodziny i sprawiedliwości. Bronimy kultury i ducha. Wiary i moralności. Tożsamości i Tradycji ${ }^{6}$

- mówi Dugin.

${ }^{5}$ А. Дугин, Святые жандармы Европы. Эссе о будущиих гранииах России и Европейской Револючии, http://falangeurasia.blogspot.se/2014/03/blog-post_9119.html (dostęp: 10.05.2014).

${ }^{6}$ Ibidem. 
Porównując politykę Rosji i USA, Dugin używa terminów „porządek” i „chaos”. Stany wprowadziły chaos w Jugosławii, Iraku, Afganistanie, przyczyniły się do rozbicia Gruzji, zamierzają to zrobić w Bośni, Turcji, Iranie, Azerbejdżanie, Armenii. Kilkanaście lat sieją chaos na Ukrainie. Obrona porządku jest zasadą konserwatywna, ale trzeba ją wzmocnić projektem przyszłościowym, duchowo i intelektualnie rozwiniętym, nasyconym treścią metafizyczną. Tylko obrona zasady porządku przed chaosem uzasadnia wejście na drogę konfliktu z USA. Dugin nazywa to misją Rosji, która nie akceptuje ani socjalizmu, ani nacjonalizmu, ani liberalizmu - pogrobowców moderny.

Takim perspektywicznym projektem geopolitycznym, realizowanym przez prezydenta Putina, jest Sojusz Euroazjatycki. Projekt ten był od początku lat 90. propagowany równolegle w Rosji (przez Ruch Euroazjatycki) i w Kazachstanie przez prezydenta Nursułtana Nazarbajewa. W 1994 r. Nazarbajew zaproponował integrację przestrzeni postradzieckiej i przedłożył projekt konstytucji będący kopią konstytucji Unii Europejskiej (na mocy traktatu z Maastricht) ${ }^{8}$. Dalekowzroczność Nazarbajewa nie była cechą ówczesnych władz Federacji Rosyjskiej. Do urzeczywistnienia projektu euroazjatyckiego niezbędny jest sojusz przede wszystkim: Rosji, Kazachstanu, Białorusi i Ukrainy, jako twardego jądra wspólnoty cywilizacyjnej. Największym problemem w realizacji tego geopolitycznego projektu jest, według Dugina, Ukraina, która podzielona jest między dwie cywilizacje. Zachodnia Ukraina podkreśla swoją odrębność wobec Rosji. Dlatego Ukraina nie może w całości wejść do Sojuszu. Zachód podsyca nacjonalizm ukraiński do realizacji celów polityki euroatlantyckiej, ale, jak twierdzi Dugin, w ostatecznym rezultacie zostanie on potępiony.

Podobnie jak hegemonię w polityce międzynarodowej określiło przemówienie Busha w Bratysławie, tak przemówienie Putina w Monachium w 2007 r. zapowiedziało powrót Rosji do decydowania o jej kształcie. Natalia Narocznicka podkreśla, że zapowiedziało ono wówczas kres prawa wyłączności Zachodu do interpretowania zjawisk politycznych ${ }^{9}$. Putin oskarżył Zachód o uczestniczenie w wewnętrznych konfliktach, wojenną ekspansję na całym świecie. Narocznicka zwraca uwagę także na fakt, że prezydent Putin jako jedyny polityczny lider i Rosja jako jedyne państwo oficjalnie występują w obronie wartości chrześcijańskich. (Życzenia Putina dla papieża Franciszka z okazji wyboru odwoływały się do takich właśnie wartości). Postawę tę uwiarygodnia, oparta na faktach i prawie, bliska współpraca władz rosyjskich i Cerkwi oraz innych wyznań w rozwiązywaniu trudnych problemów społecznych.

${ }^{7}$ А. Дугин, Четвертый путь к русскому порядку, http://www.ruska-pravda.com/ideologiya.html (dostęp: 10.05.2014).

${ }^{8}$ А. Дугин, Постсоветское пространство начинает интегрироваться в единый стратегический блок, http://oko-planet.su/politik/politiklist/134277-aleksandr-dugin-bitva-za-ukrainu.html (dostęp: 10.05.2014).

${ }^{9}$ Газета ВЗГЛЯД взяла интервью у Наталии Алексеевны, https://www.google.pl/?gws_rd=cr\&ei (dostęp: 10.05.2014). 
Putin angażuje się w uroczystości cerkiewne, podkreślając państwowotwórczą rolę Cerkwi.

Warto przytoczyć w tym miejscu słowa wypowiedziane przez patriarchę Cyryla na spotkaniu ze studentami w Smoleńsku:

Ludzie młodzi, w średnim wieku i starzy winni czynić jedno - walczyć o to, żeby Rosja zachowała swoją niezależność. Nie formalną, ale realną - to oznacza obronę na forum międzynarodowym swojego punktu widzenia, nawet jeśli nie jest zgodny z poglądami mocarstw. Wolność to zdolność pójścia własną drogą, opartą na własnym systemie wartości. Dziś nasza niezależność budzi sprzeciw w świecie. Pewien polityk powiedział mi: „Żeby zapanował pokój w świecie, musimy was przeformatować”, to znaczy z nas zrobić ich. Ażeby do tego nie doszło, wszyscy musicie umieć rozróżniać duchy (1 Kor. 12:10), zwłaszcza gdy zaczynają was nakłaniać do uczestnictwa w chaosie. Trzeba z troską odnosić się do swojego państwa, trzeba wychowywać samych siebie i swoje dzieci zgodnie z przekonaniami, które uformowały naszą wspólnotę, które z pojedynczych ludzi uczyniły zjednoczony naród rosyjski. Jeśli nasza młodzież będzie reprezentować taką postawę, to będzie poważnym sygnałem dla tych, którzy myślą inaczej ${ }^{10}$.

W przypadku polityki wewnętrznej Rosji można odpowiedzieć na postawione na początku referatu pytania, że od 10 lat opiera ona swoją politykę na wartościach chrześcijańskich, nie naruszając wartości pozostałych trzech religii podstawowych. Sprawia to, że liczne konserwatywne środowiska w Europie patrzą z nadzieją na Rosję jako ostoję chrześcijaństwa. Narocznicka, z uwagi na funkcję przewodniczącej Instytutu Demokracji i Współpracy w Paryżu, otrzymuje listy wyrażające wdzięczność dla prezydenta i parlamentu rosyjskiego oraz dezaprobatę dla antychrześcijańskiej polityki liberałów.

Problem ten w kontekście geopolityki porusza także Dugin. Podkreśla on, że podstawową bolączką cywilizacji euroatlantyckiej jest przyjęcie koncepcji człowieka według Locka. Jest on tabula rasa, którą można dowolnie zapisać w procesie wychowania. Ignoruje się tożsamość kulturową, religijną, etniczną. Człowiek jest jedynie obywatelem. Tradycyjne imperium, w odróżnieniu od państwa narodowego, zrzesza nie obywateli, lecz narody i państwa, zachowując ich autonomię ${ }^{11}$. Dugin dostrzega w tym podstawową różnicę cywilizacyjną między Eurazją a Zachodem, a szczególnie USA. Dlatego też za konieczne uważa odtworzenie imperium euroazjatyckiego w celu obrony rodzimej cywilizacji, człowieka i wartości religijnych. Dugin oskarża USA o utrudnianie tych przedsięwzięć przez destabilizację regionu postradzieckiego, a także kontrolowanie Europy, krajów islamskich i Chin według planu sformułowanego

${ }^{10}$ Выступление святейшего патриарха кирилла (на встрече со студентами высших учебных заведений смоленской области. смоленский государственный университет, 31 августа 2013), www.patriarchia.ru, przeł. H. K.-S.

${ }_{11}^{11}$ Александр Дугин о ситуации на Украине, http://www.blagogon.ru/digest/451/ (dostęp: 10.05.2014). 
przez Pola Wolfowica i Luisa Libi w 1992 r. Kładzie on nacisk na ukształtowanie świadomości ludzi na terenach postradzieckich w duchu liberalizmu światopoglądowego. W tym celu utworzono Fundację Eurazja, której filie działają na Kaukazie i na Syberii, stymulują działalność organizacji pozarządowych, badań socjologicznych, inicjatyw oświatowych i protestanckich. USA na ścisłym terytorium WNP współorganizowały kolorowe rewolucje z wykorzystaniem informacyjnych technologii, pozarządowych organizacji itp. Kilkanaście lat trwa geopolityczna bitwa o Ukrainę. Dugin rozpatruje ten problem w kontekście wojny cywilizacji między Rosją i USA ${ }^{12}$. Dlatego wojny o Krym nie traktuje jako konfliktu między Rosją a Ukrainą, lecz jako wojnę o nowy porządek świata. Rosja, by zachować realną suwerenność, musi stanąć w obronie swojej cywilizacji, a w tym celu musi prowadzić konsekwentną politykę. Dugin podkreśla, że gwarantuje ona zbalansowanie działań USA w regionie ${ }^{13}$.

Realizowanie geopolityki nie opiera się na geografii politycznej, kolonializmie czy przewadze militarnej. Realizowanie geopolityki, i tu zgadzam się z Duginem, musi uwzględniać tradycje historyczno-kulturowe i tradycje życia społecznego.

${ }^{12}$ Александр Дугин о ситуации на Украине, http://www.blagogon.ru/digest/451/.

${ }^{13}$ А. Дугин, Геополитика Путина, http://poznavatelnoe.tv/dugin_geopolitika_putina. 